\title{
A Contribution to the Diptera fauna with some new remarkable records of the species
}

\author{
Usama M. Abu El-Ghiet ${ }^{1,2}$, Tarek M. Elsheikh ${ }^{1,3}$, Zarrag I.A. Al-Fifi ${ }^{1}$ and Hass an Ali Dawah ${ }^{4}$ \\ ${ }^{1}$ Biology Department. Faculty of Science, Jazan University, Saudi Arabia. \\ ${ }^{2}$ Plant Protection Department, Desert Research Center, Mataria, Cairo, Egypt. \\ ${ }^{3}$ Zoology Dept., Faculty of Science, Al-Azhar University, Cairo, Egypt. \\ ${ }^{4}$ Center for Environmental Research and Studies, Jazan University, Saudi Arabia. \\ Usama778@yahoo.com, telsheikh64@yahoo.com,z_alfifi@hotmail.com, dawaha@hotmail.co.uk \\ ORCID ID Usama M. Abu El-Ghiet 0000-0003-0288-4199
}

Received on: 4-8-2021

Accepted on: 23-10-2021

\begin{abstract}
Despite the richness of the Diptera (true flies) and their environmental, medical and agricultural importancethey are poorly studied in Saudi Arabia. Insect specimens were collected mainly using sweeping and Malaise traps, at 10 sites in southwest Saudi Arabia in 2012-2014 and 2017. Thirty nine species of Diptera belonging to 14 families were monitored, 20 of them were first time recorded in southwest Saudi Arabia namely; Ophiomyia arabica Deeming, Phytoliriomyza sp. n. near hispanica Spencer (Agromyzidae), Ommatius tenellus Van der Wulp (Asilidae), Katacamilla cavernicola Papp, Katacamilla ctenidia Barraclough, Katacamilla procavia Barraclough (Camillidae), Lasiambia sp. near albidipennis (Strobl), Rhopalopterum sp. (Chloropidae), Somatiosoma eremicolum Ebejer (Chyromidae), Conops (Conops) tomentosus Kröber, Physocephala antiqua (Wiedemann), Thecophora atra (Fabricius) (Conopidae), Platypalpus albiseta (Panze), Platypalpus flavicornis (Meigen), Platypalpus pachycera (Collin) (Hybotidae), Leptometopa coquillettiHendel (Milichidae), Efflatouniella vanharteni Hauser, Phycus rufofemoratus Kröeber, Ruppellia semiflava Wiedemann (Therevidae). This study has added new Diptera records which will provide the basis for future works on Diptera. We suggest that many more species will be revealed in the country, if new provinces and localities are investigated with the use of mass trapping methods.
\end{abstract}

KEYWORDS: Diptera; Farasan; Jazan, Abha; new records; Saudi Arabia.

\section{INTRODUCTION}

Despite the species richness of the Diptera ("true flies" or "two-wing flies") fauna and their environmental, medical and agricultural importance they are poorly studied in Saudi Arabia. Diptera are among the largest orders of insects omnipresent and widely distributed insects. The order Diptera make up a very large order with 172 to 179 families and about 152,000-160000 described species which probably underestimates the actual fauna by at least a half (Evenhuis et al. 2007; Adler and Footit 2009\&Marshall 2012). These insects can be exploited in food materials and the order as a whole is of considerable economic importance (Skuhravá et al. 2010). Species of flies could perform as (a) scavengers and decomposers role in the economy of nature, e.g., Dung-flies (b) pollinators, e.g., many flower feeding species (c) parasitoids and predators feeding on other insects and used in biological control programme (d) Agricultural pests e.g., Carrot-fly (e) carry malaria, sleeping sickness and yellow fever (f) contaminates huge quantities of human food, e.g., house-fly and $(\mathrm{g})$ veterinary pests, e.g., green bottles and warble flies (Courtney et al. 2009). As yet there have been no systematic surveys of the Saudi Arabian Diptera, especially in the southwest and the fauna of this group of insects is poorly known. Surveying the fauna of Saudi Arabia would be the first step to prepare scientist to perform all sort of studies on taxonomy, biology and behaviour of the know species of Diptera in Saudi Arabia. The aim of the present work is to investigate Diptera fauna in Saudi Arabia especially southwest region, providing new records, some biological information, the world-wide distribution of the species. Valuable information and a comprehensive account of the biology, taxonomy, behaviour, natural history of Diptera of the families of Diptera reported in this study could be found in (Papp and Darvas 1998; Merritt 2003; Beuk 2002; Marshall 2012; Kirk-Spriggs and Sinclair 2017a and b). 
Usama M. Abu El-Ghiet et al., 2021

\section{MATERIAL AND METHODS}

The experiments of Diptera investigation were carried out at south-western Saudi Arabia project (see: Daw ah et al. 2019; 2020; for more information on the collecting sites), insect specimens were mainly collected using sweeping and Malaise traps, at 10 sites in southwest Saudi Arabia in 2012-2014 and 2017 (Table 1; Fig. 1-6). The sites were regularly visited at three week intervals to detect any appeared insects and collecting them in containers containing alcohol. Diptera samples sorted, and dried as desribed by Daw ah et al. (2020). They were mounted and labelled before being studied. Specimens which have been identified to genus are not counted as a new record if a species of the same genus was listed but if the genus was listed on its own, then it was counted as a new record. Whereas, reference was made to all species whichfirst published records and others.

\subsection{Specimen Identification and Deposition}

Insects were initially identified by U.M. Abu ElGhiet \& H.A.Dawah to families, genera and species using various keys. These identifications were confirmed by J.C. Deeming, M. Ebejer, at NMWCthe National Museum of Wales, Cardiff, which voucher specimens collections were deposited. Specimens were also deposited at CERS-Jazan University. Many species of Diptera are difficult to identify without reference to the terminalia. Males will give few problems when their terminalia are extended or dissected. Which is a prerequisite to Diptera species identification (Daw ah and Abdullah, 2006).

Table 1. List of sampling localities with coordinates, altitude and methods and times of collection

\begin{tabular}{|c|c|c|c|c|c|}
\hline S.N. & Locality & Coordinates & Altitude & Method & $\begin{array}{l}\text { No. of } \\
\text { traps }\end{array}$ \\
\hline 1 & $\begin{array}{l}\text { Al-Hudaithy, Abha, Asir, Maraba, } \\
\text { (mango, banana and wild plants) }\end{array}$ & $17^{\circ} 51^{\prime} \mathrm{N} 42^{\circ} 23^{\prime} \mathrm{E}$ & $226 \mathrm{~m}$ & $\begin{array}{l}\text { Using traps (Malaise } \\
\text { sw eeping, Sand fly) }\end{array}$ & Two \\
\hline 2 & $\begin{array}{l}\text { Al-Ethrebany, Asir, Keratha, (mango, } \\
\text { banana and wild plants) }\end{array}$ & $18^{\circ} 04^{\prime} \mathrm{N} 42^{\circ} 31^{\prime} \mathrm{E}$ & $994 \mathrm{~m}$ & $\begin{array}{l}\text { Malaise trap, } \\
\text { sweeping }\end{array}$ & Two \\
\hline 3 & $\begin{array}{l}\text { Abha, Asir, Hay Al-Nusub (Abha Farm } \\
\text { Centre), (vegetables and wild plants) }\end{array}$ & $18^{\circ} 13^{\prime} \mathrm{N} 42^{\circ} 30^{\prime} \mathrm{E}$ & $2199 \mathrm{~m}$ & $\begin{array}{l}\text { using trap (Malaise ), } \\
\text { sw eeping }\end{array}$ & Two \\
\hline 4 & $\begin{array}{l}\text { Jazan, Abu-Aresh, Mohammed Bakreen, } \\
\text { Chicken and Sheep Farm }\end{array}$ & $16^{\circ} 56^{\prime} \mathrm{N} 42^{\circ} 49^{\prime} \mathrm{E}$ & $60 \mathrm{~m}$ & $\begin{array}{l}\text { Malaise trap, Light } \\
\text { Trap }\end{array}$ & One \\
\hline 5 & Jazan (Al-Mahdage Village) & $17^{\circ} 00^{\prime} \mathrm{N} 42^{\circ} 50^{\prime} \mathrm{E}$ & $80 \mathrm{~m}$ & $\begin{array}{l}\text { Using traps } \\
\text { (Malaise), sweeping }\end{array}$ & Two \\
\hline 6 & $\begin{array}{l}\text { Jazan, Sabya (common plants: Sorghum } \\
\text { bicolor,Sporobolushelvolus, Cenchruscili } \\
\text { aris) }\end{array}$ & $17^{\circ} 07^{\prime} \mathrm{N} 42^{\circ} 38^{\prime} \mathrm{E}$ & $70 \mathrm{~m}$ & Sweeping & Two \\
\hline 7 & $\begin{array}{l}\text { Jazan, Wadi Shahdan (common plants: } \\
\text { Sorghum bicolor, Corchorusolitorius) }\end{array}$ & $17^{\circ} 19^{\prime} \mathrm{N} 42^{\circ} 34^{\prime} \mathrm{E}$ & $40 \mathrm{~m}$ & Sweeping & Three \\
\hline 8 & $\begin{array}{l}\text { Jazan-Morgan mangrove (Mangrove } \\
\text { plant (Avicennia marina) }\end{array}$ & $16^{\circ} 50^{\prime} \mathrm{N} 42^{\circ} 34^{\prime} \mathrm{E}$ & $0 \mathrm{~m}$ & Sweeping & One \\
\hline 9 & $\begin{array}{l}\text { Jazan, Ahad al Masarihah ( Corchorus } \\
\text { olitorius) }\end{array}$ & $16^{\circ} 43^{\prime} \mathrm{N} 42^{\circ} 55^{\prime} \mathrm{E}$ & $30 \mathrm{~m}$ & Sweeping & Two \\
\hline 10 & $\begin{array}{l}\text { Jazan, Farasan Island, Aziz Yousef } \\
\text { Village }\end{array}$ & $16^{\circ} 40^{\prime} \mathrm{N} 42^{\circ} 50^{\prime} \mathrm{E}$ & $3 \mathrm{~m}$ & $\begin{array}{l}\text { sweeping and } \\
\text { Malaise trap }\end{array}$ & One \\
\hline
\end{tabular}


Scientific Journal of Agricultural Sciences 3 (2): 204-218, 2021

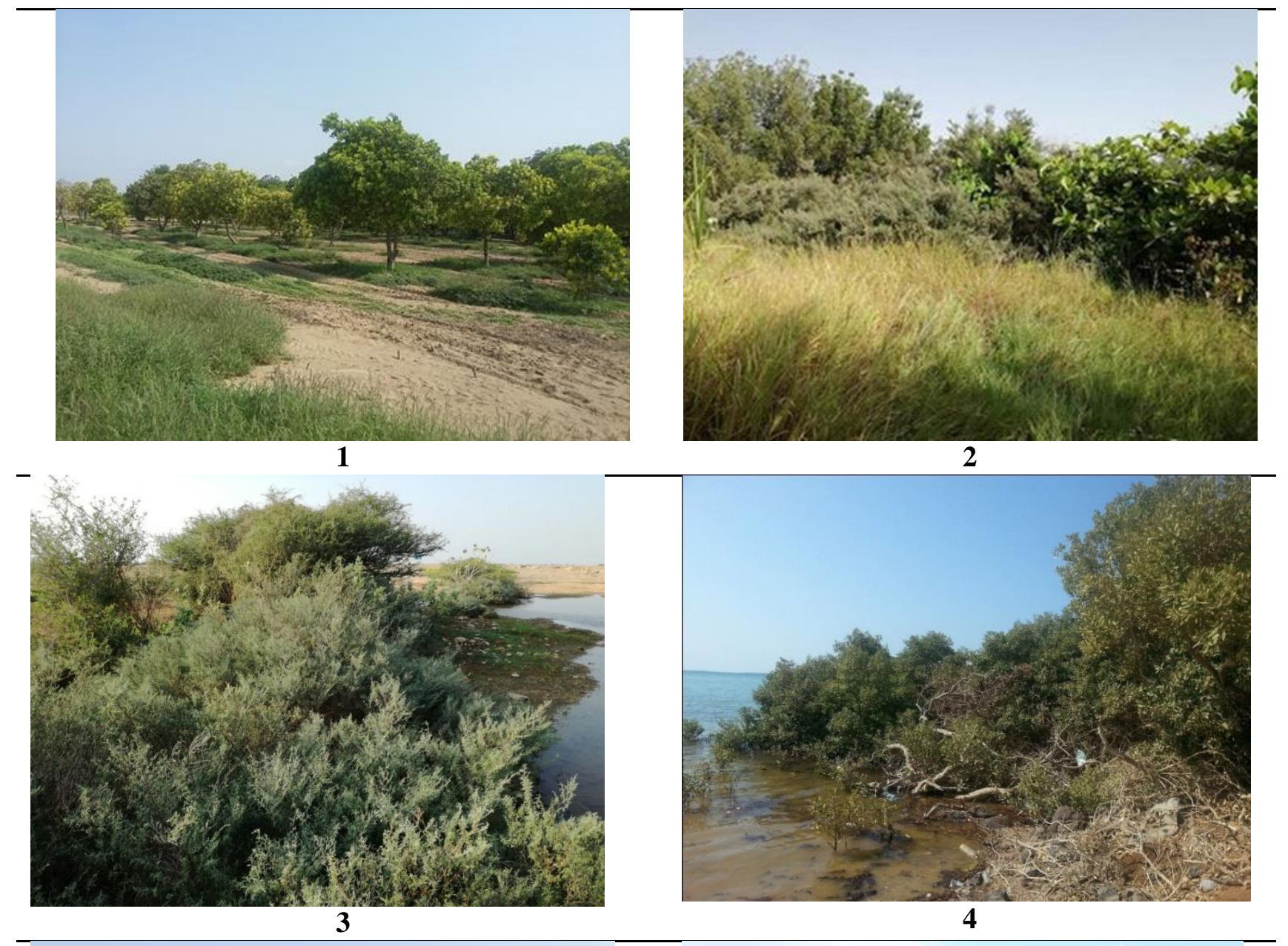

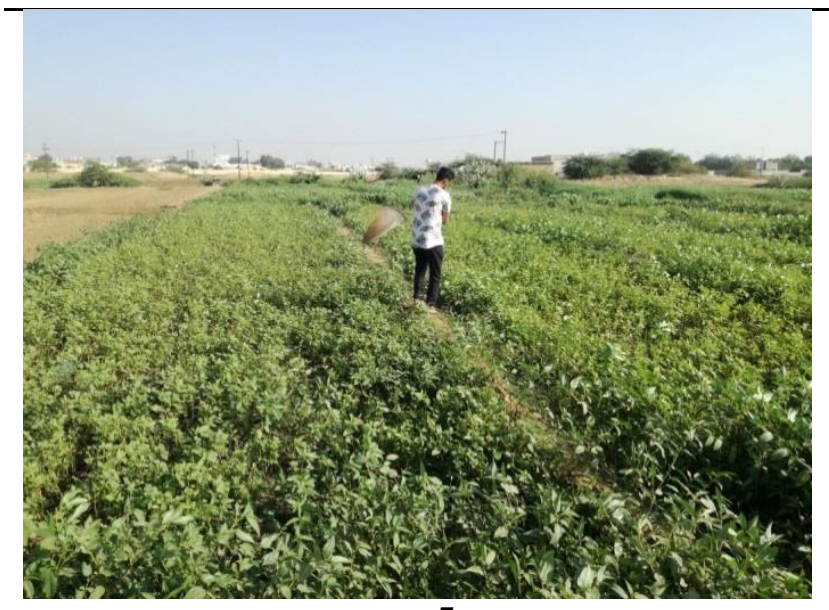

5

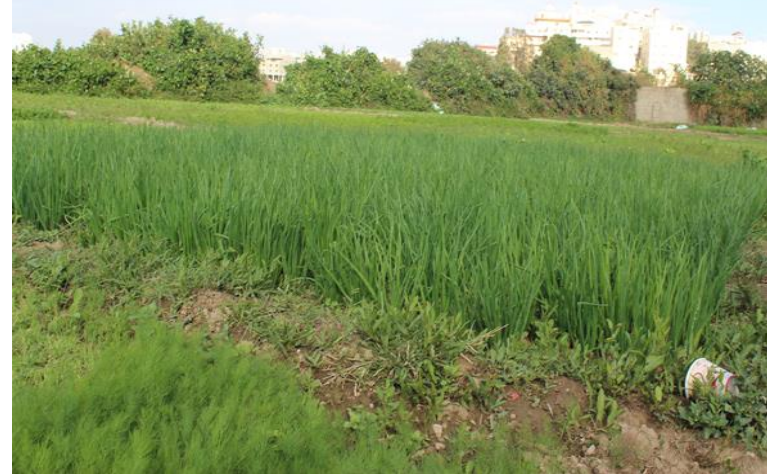

6

Fig 1-6. The Saudi Arabian sites where Diptera were collected in the present study: 1-Jazan, Abu Aresh, Al-Mahdag village 2- Jazan, Farasan Island, Aziz Yousef Village 3- Jazan, Farasan Island, Sajeid 4- Jazan-Morgan 5- Jazan, Ahad al Masarihah 6- Asir, Abha, Hay Al-Nusub.

\subsection{Distribution and Nomenclature}

The following references were used for species distribution which are also given in the text; (Dawah et al. 2019; Smit et al. 2017; Hauser 2017; Stuke 2008; 2017; Deeming 1971; 1998; 2003; 2006; 2008; 2011; 2017; Deeming and Al-Dhafer 2012; Ebejer
2007; Bosák and Hradský 2011; Badrawy and Mohammad 2011; Khaghaninia and Kazerani 2014; Oldroyd 1980, Lehr 1988; Kirk-Spriggs et al. 2002; Barraclough 1998; Canzoneri and Meneghini 1983; Mathis and Zatwarnicki 1995; Pont 1973; Friedberg and Kugler 1989). We additionally, used the Diptera 


\section{Usama M. Abu El-Ghiet et al., 2021}

Catalogue of the Afrotropical region (Crosskey 1980).

When the species are not present in Crosskey (1980), Catalogue of Palaerctic Diptera (eds., Á. Soós and L. Papp) was used or other references which are given for the species listed in this article. There is no recent catalogue available on the website or in print for most of the families involved in this article. These catalogues are present only in some European libraries or in some museums. Therefore, one of us (H.A.D) drew on these references at National Museum of Wales, UK to find information about the distribution of these species. The countries of all the species distribution are arranged alphabetically and in many species according to their geographical zones.

\section{RESULTS}

Thirty nine species of Diptera belonging to 14 families were observed includes 20 species were first time record in southwest region of Saudi Arabia including three taxa Phytoliriomyza sp. n. near hispanica Spencer; Lasiambia sp. near albidipennis (Strobl); Rhopalopterum sp. could not be identified safely to species level because there were no adequate identification keys or males were missing in the collected material (Table 2). Some information about the species were also provided such as distribution over the world.

Table 2. List of Diptera species in Saudi Arabia.

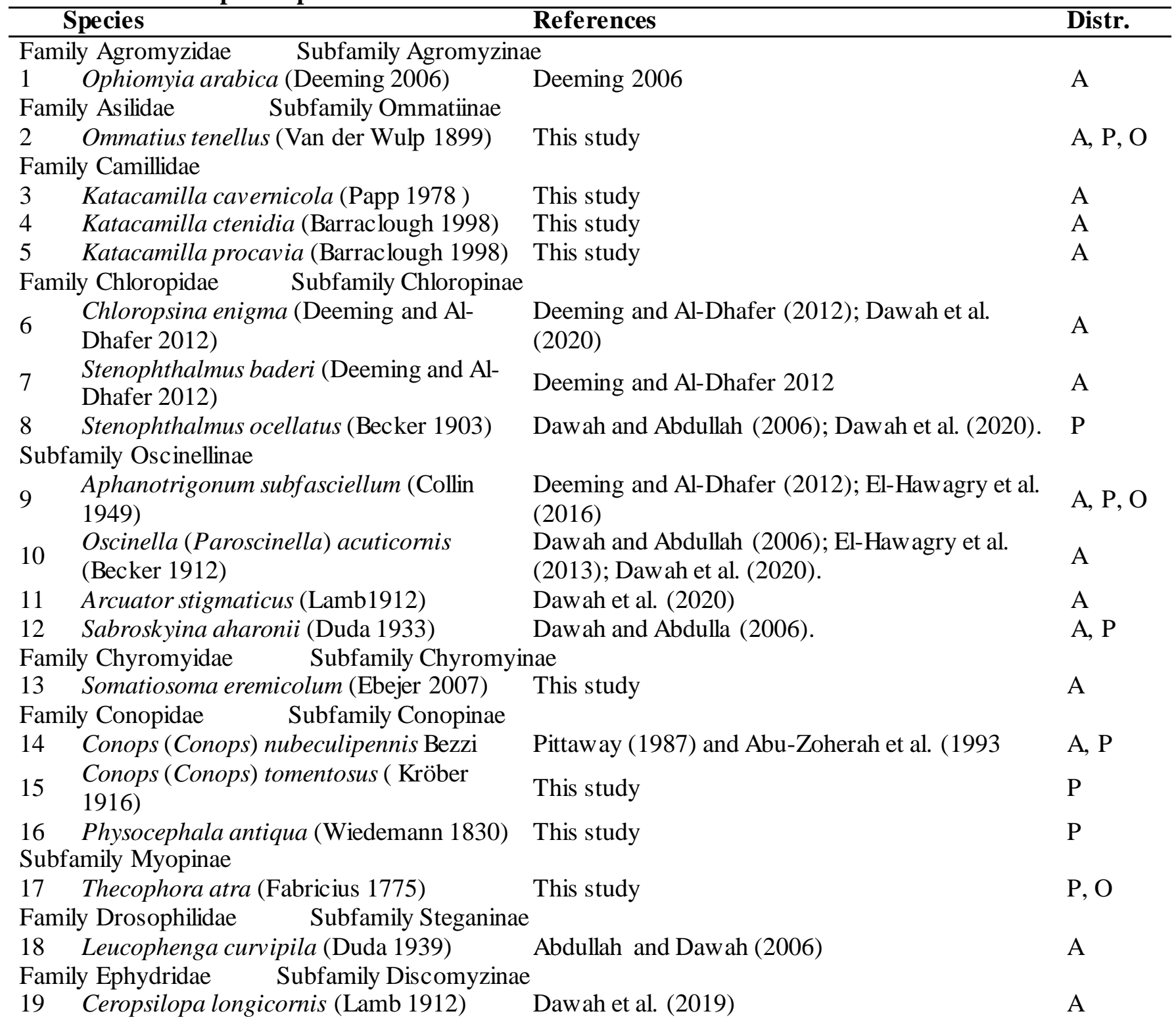


Scientific Journal of Agricultural Sciences 3 (2): 204-218, 2021

\begin{tabular}{|c|c|c|c|}
\hline & Species & References & Distr. \\
\hline 20 & Psilopa nilotica (Becker 1903) & $\begin{array}{l}\text { Dawah and Abdullah (2006); El-Hawagry et al. } \\
\text { (2017); Dawah et al. (2019) }\end{array}$ & A, P \\
\hline 21 & $\begin{array}{l}\text { Scoliocephalus monochaeta (Steyskal } \\
1928 \text { ) }\end{array}$ & Dawah et al. (2019) & $\mathrm{P}$ \\
\hline \multicolumn{4}{|c|}{ Family Hybotidae $\quad$ Subfamily Tachydromiinae } \\
\hline 22 & Platypalpus albiseta (Panze 1806) & This study & $\mathrm{P}$ \\
\hline 23 & Platypalpus flavicornis (Meigen 1822) & This study & $\mathrm{P}$ \\
\hline 24 & Platypalpus pachycera (Collin 1949) & This study & $\mathrm{P}$ \\
\hline 25 & Platypalpus subaenescens (Collin 1960) & Soós and Hůrka (1986) & $\mathrm{A}, \mathrm{P}$ \\
\hline \multicolumn{4}{|c|}{ Family Milichiidae $\quad$ Subfamily Madizinae } \\
\hline 26 & Desmometopa varipalpis (Malloch 1927) & Deeming (1998). & A, $\mathrm{P}$ \\
\hline 27 & Leptometopa coquilletti (Hendel 1907) & This study & A \\
\hline \multicolumn{4}{|c|}{ Subfamily Milichiinae } \\
\hline 28 & Milichia pubescens (Becker 1907) & Dawah and Abdullah (2007). & $\mathrm{A}, \mathrm{P}$ \\
\hline 29 & Milichiella lacteipennis(Loew 1866) & Dawah and Abdullah (2007). & $\mathrm{CO}$ \\
\hline \multicolumn{4}{|c|}{ Family Muscidae Subfamily Atherigoninae } \\
\hline 30 & $\begin{array}{l}\text { Atherigona (Atherigona) lineata (Adams } \\
\text { 1905) }\end{array}$ & Dawah and Abdullah (2009). & A \\
\hline 31 & $\begin{array}{l}\text { Atherigona (Atherigona) soccata } \\
\text { (Rondani 1871) }\end{array}$ & Pont (1991) and Daw ah and Abdullah (2009). & $\mathrm{A}, \mathrm{P}$ \\
\hline \multicolumn{4}{|c|}{ Family Syrphidae } \\
\hline 32 & Syritta latitarsata (Macquart 1842) & Abu-Zoherah, et al. (1993) & A, $\mathrm{P}$ \\
\hline \multicolumn{4}{|c|}{ Family Tephritidae } \\
\hline 33 & $\begin{array}{l}\text { Metasphenisca negeviana (Freidberg } \\
\text { 1974) }\end{array}$ & Freidberg and Kugler (1989) & $\mathrm{P}$ \\
\hline \multicolumn{4}{|c|}{ Family Therevidae } \\
\hline 34 & Efflatouniella vanharteni Hauser $\left(\Upsilon_{\cdot}{ }^{\prime} 7\right)$ & This study & A \\
\hline 35 & Phycus rufofemoratus Kröeber (1913) & This study & A, $\mathrm{P}$ \\
\hline & Ruppellia semiflava Wiedemann (1830) & This study & $\mathrm{A}, \mathrm{P}$ \\
\hline \multicolumn{4}{|c|}{ Diptera not identified to the species level } \\
\hline \multicolumn{4}{|c|}{ Agromyzidae $\quad$ Subfamily Phyromyzinae } \\
\hline 37 & $\begin{array}{l}\text { Phytoliriomyza sp. } \mathrm{n} \text {. } \\
\text { near hispanica } \text { Spencer }\end{array}$ & This study & $\mathrm{A}, \mathrm{P}$ \\
\hline $\mathrm{Ch}$ & opidae Subfamily Chloropinae & & \\
\hline 38 & $\begin{array}{l}\text { Lasiambia sp. near albidipennis (Strobl } \\
\text { 1893) }\end{array}$ & This study & A, P \\
\hline 39 & Rhopalopterum sp. & This study & $\mathrm{P}$ \\
\hline
\end{tabular}

(*Co: Cosmopolitan; A: Afrotropical; P: Palaearctic; O: Oriental)

Family Agromyzidae (Subfamily Agromyzinae)

Ophiomyia arabica (Deeming 2006)

Specimens examined. 3ð̄, Jazan, Sabya, 16.ix.2017, sweeping, U.M. AbuEl-Ghiet (CERS)

Distribution. First record in Saudi Arabia described previously in Oman and Yemen (Deeming 2006).

Family Asilidae (Subfamily Ommatiinae)

Ommatius tenellus (Van der Wulp 1899)

Specimens examined. 10̂, Jazan, Sabya, 16.ix.2017, sweeping, U.M. AbuEl-Ghiet (CERS)
Distribution. First record in Saudi Arabia, and also recorded in south Yemen and the Region of Afrotropical: Chad, Eriteria, Niger, Senegal, Sudan, United Arab Emirates and Yemen; Palearctic Region: Algeria, Arabic states, China, Egypt, Iran, Transcaucasus and Israel; Oriental Region: India and China (Oldroyd 1980; Lehr 1988; Bosák and Hradský 2011).

\section{Family Camillidae}

The Camillidae are not known in the entire Middle East region. Barraclough (2004) described three new 


\section{Usama M. Abu El-Ghiet et al., 2021}

species from Arabian Peninsula two of them from Saudi Arabia (Katacamilla gallagheri, K. vanharteni). Katacamilla cavernicola (Papp 1978)

Specimens examined. 1ð, 1q, Jazan, Farasan Island, Aziz Yousef Village, 2-15.iii.2014, Malaise trap, H.A. Daw ah (CERS; NMWC).

Distribution. First record in Saudi Arabia and described formerly in Namibia.

Remarks. Kirk-Spriggs, et al. (2002) described the third instar larva and puparium of $K$. cavernicola. It has been reared from the dung of the common slitfaced bat (Nycteris thebaica E. Geoffroy SaintHilaire) and of the rock pigeon (Columba livia Gmelin).

Katacamilla ctenidia (Barraclough 1998)

Specimens examined. 2^, 1q, Jazan, Farasan Island, Aziz Yousef Village, 2-15.iii.2014, Malaise trap, H.A. Daw ah (CERS; NMWC).

Distribution. First record in Saudi Arabia and described early in Nigeria from a single male collected by Dr John Deeming who swept it from dead grass under extremely dry conditions in the far north of Nigeria and it has not since been recorded (Dr J. Deeming, pers. comm.).

Katacamilla procavia (Barraclough 1998)

Specimens examined. 1 $\hat{\jmath}, 1 q$, Jazan, Farasan Island, Aziz Yousef Village, 2-15.iii.2014, Malaise trap, H.A. Daw ah (CERS; NMWC).

Distribution. First record fin Saudi Arabia and described earlier from Namibia.

Remarks. This is the only species in the genus that has been reared from Hyrax Huxley dung in Namibia. Barraclough (1998) reported that all other species of Katacamilla are found in caves, suggesting that the association with bat roosts and their accumulation of dung in caves is a specialization of the genus Katacamilla.

\section{Family Chloropidae (Subfamily Chloropinae)}

Chloropsina enigma (Deeming and Al-Dhafer 2012)

Specimens examined. 29, Jazan, Sabya, 16.ix.2017, sweeping, U.M. AbuEl-Ghiet.

Distribution. Previously reported in Saudi Arabia by Deeming and Al-Dhafer (2012); Dawah et al. (2020). It was described from Nigeria and is also recorded from the Gambia, Mali, Saudi Aabia and Yemen.

Stenophthalmus baderi (Deeming and Al-Dhafer 2012)

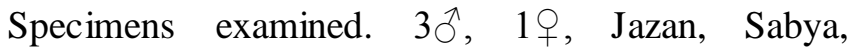
16.ix.2017, sweeping, U.M. AbuEl-Ghiet (CERS)

Distribution. Described earlier in Saudi Arabia.

Stenophthalmus ocellatus (Becker 1903)

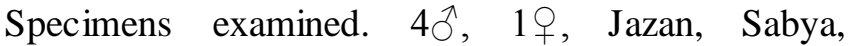
16.ix.2017, sweeping, U.M. AbuEl-Ghiet (CERS)

Distribution. Previously recorded in Saudi Arabia by Daw ah and Abdullah (2006); Dawah et al. (2020), It was described from Egypt and has also been recorded from India, Turkmenia and Sudan (Deeming and AlDhafer 2012).

Biology. It was reared from sugarcane in Egypt (Dr J. Deeming, pers. comm.).

Subfamily Oscinellinae

Aphanotrigonum subfasciellum (Collin 1949)

Specimens examined. 1q, Jazan, Sabya, 16.ix.2017, sweeping, U.M. AbuEl-Ghiet (CERS).

Distribution. Previously recorded in Saudi Arabia by Deeming and Al-Dhafer (2012); El-Hawagry et al. (2016), and described in Egypt and further are listed in Deeming and Al-Dhafer (2012); Deeming (2011). Oscinella (Paroscinella) acuticornis (Becker 1912)

Specimens examined. 2^, $3 \uparrow$, Jazan, Wadi Shahdan, 23.ix.2017, sweeping, U.M. Abu El-Ghiet (CERS).

Distribution. Formerly recorded in Saudi Arabia by Dawah and Abdullah (2006); El-Hawagry et al. (2013); Dawah et al. (2020), it was described from Ethiopia and is further recorded from Gambia, Kenya, Namibia, Nigeria, Oman, Seychelles and Yemen (Sabrosky 1980; Deeming 2003).

Biology. Deeming (2003) recorded that this species attacks some economically important cereals (e.g. Eragrostis tef (Zucc.) Trotter (Poaceae).

Arcuator stigmaticus (Lamb1912)

Specimens examined. 1ठ, Jazan, Sabya, 16.ix.2017, sweeping, U.M. AbuEl-Ghiet (CERS).

Distribution. Recently recorded inSaudi Arabia by Dawah et al. (2020), and it was described from the Seychelles Islands. It is widespread throughout the Afrotropical Regions (Deeming and Al-Dhafer 2012). Sabroskyina aharonii (Duda 1933)

Specimens examined. 19, Jazan, Sabya, 16.ix.2017, sweeping, U.M. AbuEl-Ghiet (CERS)

Distribution. Previously recorded in Saudi Arabia by Daw ah and Abdulla (2006) and described as a variety of Oscinella sziladyi Duda from Palestine and further records are listed in Sabrosky (1980).

\section{Family Chyromyidae (Subfamily Chyromyinae)}

Somatiosoma eremicolum (Ebejer 2007)

Specimens examined. 1§, Jazan, Sabya, 16.ix.2017, sweeping, U.M. AbuEl-Ghiet (CERS). Det. by Ebejer. Distribution. First record in Saudi Arabia, it was described in United Arab Emirates (Ebejer 2007). 


\section{Scientific Journal of Agricultural Sciences 3 (2): 204-218, 2021}

\section{Family Conopidae}

There are about 800 species in 56 genera of four subfamilies, Conopinae, Myopinae, Dalmanniinae and Stylogasterinae described worldwide (Gibson and Skevington 2013; Pape and Thompson 2013). Larvae are internal parasitoids of adult bees and wasps mainly of Aculeate Hymenoptera with a few species parasitoid on Orthoptera (Askew 1971; Smith and Peterson 1987). Some Stylogastrinae have been reared from crickets and cock-roaches (Freeman 1966). Larvae of conopids develop inside the bee or wasp, ultimately killing the host before pupating within the dead-host's abdomen (Marshall 2012; Schmid-Hempel and Müller 1991). Conopids in general are not particularly host specific as some species are recorded from a range of host aculeate Hymenoptera, sometimes including both wasps and bees (Marshall 2012). Conopidae are of little economic importance except when they attack pollinators (Cameron et al. 2011). Skevington et al. (2010) provided a detailed of the biology of Conopidae. The Conopidae classification to subfamilies is according to Stuke (2017) and Mukhopadhyay et al. (2015).

Subfamily Conopinae

Conops (Conops) nubeculipennis Bezzi 1901

Specimens examined. 10, Asir, Karatha, AlEthrebany Fruit Farm, 1-25.v.2013, Malaise trap, H.A. Dawah (CERS); 1 , Jazan, Abu-Aresh, Al-Mahdag Village, 3-9.ii.2012, Malaise trap, H.A. Dawah (CERS).

Distribution. This species was previously recorded from Saudi Arabia by Walker and Pittaway (1987) and Abu-Zoherah et al. (1993). It was described from Ethiopia (Eritrea) and is further recorded from the Palaearctic Regions: Egypt; Iran, Iraq, and Turkey: Afrotropical Regions: Cameroun, Mozambique, Saudi Arabia and Yemen (Chvála and Smith 1988; Smith 1980; Stuke et al. 2008).

Conops (Conops) tomentosus (Kröber 1916)

Specimens examined. 19, Jazan, Abu Aresh, AlMahdag Village, 5-25.iv.2012, Malaise trap, H.A. Daw ah (CERS).

Distribution. First record in Saudi Arabia, it was previously described from Turkmenien and common in Europe (Chvála and Smith 1988).

Physocephala antiqua (Wiedemann 1830)

Specimens examined. 19 Asir, Maraba, Al-Hudaithy Fruit Farm, 14.iii.-1.iv.2013, Malaise trap, H.A. Dawah (CERS); 1 9 , Jazan, Abu-Aresh, Al-Mahdag Village, 3-9.ii.2012, Malaise trap, H.A. Dawah (CERS).
Distribution. The first record in Saudi Arabia, It was described in Egypt and the Palaearctic Regions: Algeria, Arabic states, China, Egypt, Europe (southwest), Iran, Mongolia and Syria (Chvála and Smith 1988).

Subfamily Myopinae

Thecophora atra (Fabricius 1775)

Specimens examined. 1ठ̄, Najran, Al-Shurfa, Saleh Maqbol Farm, 13-30.iii.2013, Malaise trap, H.A. Dawah (CERS); 19 , Asir, Abha, Hay Al-Nusub (Abha Farm Centre), 17.vii-9.viii.2014, Malaise trap, H.A. Dawah (CERS).

Distribution. This is the first record from Saudi Arabia. It was described from Denmark (Havniae; the old name for Copenhagen). It was recorded from the Palaearctic Region: Europe (Russia) and Iran: Oriental Region; India (Chvála and Smith 1988; Khaghaninia and Kazerani 2014).

\section{Family Drosophilidae (Subfamily Steganinae)}

Leucophenga curvipila (Duda 1939)

Specimens examined. 1 $\hat{\jmath}$, Jazan-Morgan mangrove 21.x.2017, sweeping, U.M. AbuEl-Ghiet (CERS)

Distribution. Previously recorded in Saudi Arabia by Daw ah and Abdullah (2006) and described in Uganda, Cameroun, Congo, Ethiopia, Ivory Coast, Mozambique, Nigeria, Tanzania (Tsacas 1980).

Remarks. Some species of Leucophenga are known to have larvae that live as commensals in spittle or froth produced by nymphs of Cercopidae (Hemiptera) (Ashburner 1981).

\section{Family Ephydridae (Subfamily Discomyzinae)}

Ceropsilopa longicornis (Lamb, 1912)

Specimens examined. 1 $\hat{\jmath}$, Jazan-Morgan mangrove 21.x.2017, sweeping, U.M. AbuEl-Ghiet (CERS).

Distribution. Recently recorded in Saudi Arabia by Dawah et al. (2019) and described from Seychelles and listed in Dawah et al. (2019).

Psilopa nilotica (Becker 1903)

Specimens examined. 2へ̂, Jazan- Sabya, 16.ix.2017, sweeping, U.M. Abu El-Ghiet (CERS).

Distribution. Previously recorded in Saudi Arabia by Dawah \& Abdullah (2006); El-Hawagry et al. (2017); Dawah et al. (2019). The species was described in Sudan, Palaearctic Region: Afghanistan, Algeria, Egypt, Ethiopia and Tunisia (Cogan, 1980; Canzoneri and Meneghini 1983; Mathis and Zatwarnicki 1995).

Biology. Canzoneri and Meneghini (1983) reported that this species found to occur on Phragmites sp. in Italy.

Scoliocephalus monochaeta (Steyskal 1928) 


\section{Usama M. Abu El-Ghiet et al., 2021}

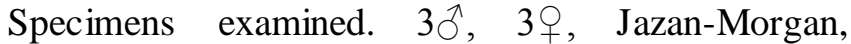
mangrove, 21.x.2017, sweeping, U.M. AbuEl-Ghiet (CERS)

Distribution. Recently recorded in Saudi Arabia by Dawah et al. (2019) and described in Egypt (Cogan 1984; Mathis and Zatwarnicki 1995). There is no further record of this species.

\section{Family Hybotidae}

There are over 2000 described species worldwide classified into subfamilies: the Hybotinae, Oedaleinae, Ocydromiinae, Tachydromiinae and Trichininae (Yang et al., 2007; Marshall 2012). They have a needle like proboscis directed forw ard obliquely. The hybotids inhabit a variety of ecological habitats such as leaf litter, seashores, beaches and flowering plants. They hunt in flight and prefer wooded areas. The larvae are predacious and live in soil. Generally, the adult hybotids are predators; except for some species of Ocydromiinae (Chvála 1983; Collins and Wiegmann, 2002). Additionally, Hybotidae is a vector of Wolbachia a parasite responsible for affecting the reproductive potential of its host (Martin et al. 2013). The classification of Hybotidae to subfamilies and tribes is according to Kahanpaa (2014).

Subfamily Tachydromiinae

Platypalpus albiseta (Panze 1806)

Specimens examined. 1 $\lesssim$, Najran, Al-Shurfa, Saleh Maqbol Farm, 1-29.iv.2013, Malaise trap, H.A. Daw ah (CERS).

Distribution. First record in Saudi Arabia. Whereas, it described without type-locality being specified (Germany?). It is recorded from Algeria Europe and Tunisia (Chvála and Kovalev 1989)

Platypalpus flavicornis (Meigen, 1822)

Specimens examined. 19, Najran, Al-Shurfa, Saleh Maqbol Farm, 1-29.iv.2013, Malaise trap, H.A. Daw ah (CERS).

Distribution. First record in Saudi Arabia and it was described without type-locality being specified (Europe). It is recorded from Algeria, Europe (widespread) (Chvála and Kovalev 1989).

Platypalpus pachycera (Collin, 1949)

Specimens examined. 19, Najran, Al-Shurfa, Saleh Maqbol Farm, 1-29.iv.2013, Malaise trap, H.A. Dawah (CERS).

Distribution. First record in Saudi Arabia, additional it was recorded in Egypt (Chvála and Kovalev 1989).

Platypalpus subaenescens (Collin 1960)

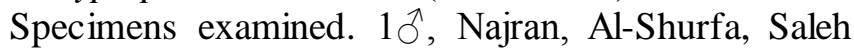
Maqbol Farm, 1-29.iv.2013, Malaise trap, H.A. Dawah (CERS).
Distribution. Previously recorded in Saudi Arabia by Soós and Hurka (1986), this species was further recorded from Egypt, Jordan, Palestine, Saudi Arabia, Sudan and Yemen (Chvála and Kovalev 1989).

\section{Family Milichiidae (Subfamily Madizinae)}

Desmometopa varipalpis (Malloch, 1927)

Specimens examined. 1今̄, 1ㅇ, Jazan, Wadi Shahdan, 23.ix.2017, sweeping, U.M. Abu El-Ghiet (CERS)

Distribution. This species was previously recorded from Saudi Arabia by Deeming (1998). It was described from New South Wales, Australia. It is widespread in the Afrotropical Region, Saudi Arabia and Yemen, from Ghana to north east Africa: east Africa, Zaire and Ascension 1. Palearctic Region: widespread in the Middle East. Oriental Region: Hawaii; North America; South America (Sabrosky1980; Deeming 1998). It was found in Australia on board a ship that had sailed from Kuwait (Sabrosky 1983).

Remarks. It was reported that $D$. varipalpis could be very annoying when hovering around the faces and getting into the eyes. The flies were found in a hospital operating room and in a dairy cheese room (Sabrosky 1983; Ferrar 1987).

Leptometopa coquilletti (Hendel 1907)

Specimens examined. 1 Jazan, Wadi Shahdan, 23.ix.2017, sweeping, U.M. Abu El-Ghiet (CERS).

Distribution. First record in Saudi Arabia, it was described from Yemen (Papp 1984).

Remarks. Okaeme (1983) records this species from skin lesions and infections on zebu cattle at Yelwa, which is a rather dry area of northern Nigeria.

Subfamily Milichiinae

Milichia pubescens (Becker 1907)

Specimens examined. 1 गे, Jazan, Wadi Shahdan, 23.ix.2017, sweeping, U.M. AbuEl-Ghiet (CERS).

Distribution. Previously recorded from Saudi Arabia by Dawah and Abdullah (2007), it w described in the Canary Islands. It has been further recorded from Formosa, Afrotropical Region and the Palearctic Region: Egypt, Corfu, Palestine and Pakistan (Sabrosky 1980; Papp 1984; Deeming 2017).

Remarks. It was recorded as being reared from latrines by Deeming and Baez 1985, who also described the puparium.

Milichiella lacteipennis (Loew 1866)

Specimens examined. 1§, Jazan, Wadi Shahdan, 23.ix.2017, sweeping, U.M. AbuEl-Ghiet (CERS)

Distribution. Previously recorded in Saudi Arabia by Dawah and Abdullah (2007), this species was described from Cuba. It was common in the Afrotropic al Region: Ascension I, Cape Verde Islands, 


\section{Scientific Journal of Agricultural Sciences 3 (2): 204-218, 2021}

Madagascar, Réunion, St. Helena, Seychelles and Nigeria; Nearctic, Neotropical, Oriental and Palearctic Regions; Madeira (Sabrosky1980; Papp 1984).

\section{Family Muscidae (Subfamily Atherigoninae)}

Atherigona (Atherigona) lineata (Adams 1905)

Specimens examined. 1ठ, Jazan, Sabya, 16.ix.2017, sweeping, U.M. Abu El-Ghiet (CERS).

Distribution. Previously recorded in Saudi Arabia by Daw ah and Abdullah (2009), Oman, Saudi Arabia and United Arab Emirates (Deeming 2008; Dawah and Abdullah 2009).it was described from Salisbury, Zimbabwe and further recorded from Cameroun, Kenya, Nigeria, South Africa and Tanzania (Pont 1980; 1991).

Biology. It is a pest of sorghum (e.g., Sorghum bicolour Moench), but it has been recorded from other hosts, too (e.g., Paspalum scrobiculatum L., Setaria pumila Poir (Skidmore 1985; Pont 1991).

Atherigona (Atherigona) soccata (Rondani, 1871)

Specimens examined. 1ð, Jazan, Sabya, 16.ix.2017, sweeping, U.M. AbuEl-Ghiet (CERS).

Distribution. This species was previously recorded from Oman and Saudi Arabia by Pont (1991) and then from Saudi Arabia by Dawah and Abdullah (2009). It w as described from Italy and recorded from different parts of Afrotropical region (including Mauritius, Réunion, Sudan), North Africa to Middle East, Burma, India, Pakistan, Thailand and Uganda (Deeming 1971; Pont 1973, 1980, 1986).

\section{Family Syrphidae}

Syritta latitarsata (Macquart 1842)

Specimens examined. 1ð, Jazan, Sabya, 16.ix.2017, sweeping, U.M. AbuEl-Ghiet (CERS)

Distribution. This species was previously recorded from Saudi Arabia by Abu-Zoherah et al. (1993). It was described from Senegal. It is known from Palearctic Regions: Egypt, Israel and Pakistan; and Afrotropical Region: Angola, Gambia, Namibia and South Africa and United Arab Emirates (Smit et al. 2017).

\section{Family Tephritidae}

Tephritidae are small to medium sized $(2.5-10 \mathrm{~mm})$, often brightly colored or patterned bodied flies usually with picture wings. There are about 4400 species distributed world-wide, categorized in almost 500 genera (Norrbom and Condon, 2010). They are essentially entirely terrestrial in their habitat selection, and grow at the margins of lakes and marshes (Merritt et al. 2003). The larvae of almost all Tephritidae are phytophagous. They feed on only one plant species (monophagous) or on several, usually related plant species (polyphagous).

Metasphenisca negeviana (Freidberg 1974)

Specimens examined. 19, Jazan, Ahad al Masarihah, 18.xi.2017, sweeping, U.M. Abu El-Ghiet (CERS)

Distribution. Previously recorded in Saudi Arabia by (Freidberg and Kugler 1989), it was described from Palestine and is further recorded from Near East.

Remarks. This species bred from Blepharis attenuate Napper (Acanthaceae) (Freidberg 1974).

\section{Family Therevidae}

The family Therevidae comprises about 1170 described species in 128 genera occurring in all geographical regions except Antarctica (Winterton et al., 2015).Adults are nectar feeders, whereas the larvae are voracious, fossorial predators of soil arthropods characterized by a secondarily segmented abdomen and an apically spatulate tentorial rod (Irwin and Lyneborg 1981a and b; Majer 1997)

Subfamily Phycinae

Efflatouniella vanharteni (Hauser, 2017)

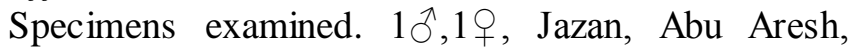
Mohammed Bakreen Farm, 24.iv.2013, Malaise trap, H.A. Dawah (CERS; NMWC).

Distribution. First record in Saudi Arabia, it was described recently from United Arab Emirates and further in Oman and Yemen (Hauser 2017).

Phycus rufofemoratus (Kröeber, 1913)

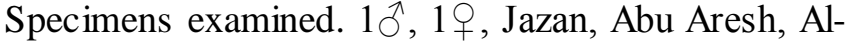
Mahdag Village, 1-15.xii.2012, Malaise trap, H.A. Daw ah (CERS).

Distribution. First record in Saudi Arabia, it was described from Yemen and Ethiopia, Jordan, Niger and Sudan (Lyneborg 1980; 1989).

Ruppellia semiflava (Wiedemann, 1830)

Specimens examined. 1엉 Jazan, Abu Aresh, AlMahdag Village, 2-4..xi.2012, Malaise trap, H.A. Dawah (CERS); 19, Jazan, Abu Aresh, Mohammed Bakreen Farm, 20.v.2013, Malaise trap, H.A. Dawah (CERS); 2 , Asir, Maraba, Al-Hudaithy Fruit Farm, 1-16.iii.2013, Malaise trap, H.A. Dawah (CERS); 3 , same data but, 14.iii.-1.iv.2013 (CERS).

Distribution. First record in Saudi Arabia, it was previously described from Egypt or Ethiopia (holotype labelled, Abyssinia) and is further recorded from Egypt, Ethiopia, Israel, Oman, Sudan, United Arab Emirates and Yemen (Lyneborg 1980; 1989; Badrawy and Mohammad 2011; Hauser 2017).

Remarks. Hauser (2017) reported that this species has colour variation where female could be deep black to nearly orange and the males are darker than the females. 


\section{Usama M. Abu El-Ghiet et al., 2021}

Diptera not identified to the species level

Taxa that were recorded in this study could not be identified to species level are listed below. These specimens could be made available to subsequent workers who wish to revise the family or particular genus.

Agromyzidae

Subfamily Phyromyzinae

Phytoliriomyza sp. n. near hispanica Spencer

Specimens examined. 1ð, Jazan, Sabya, 16.ix.2017, sweeping, U.M. AbuEl-Ghiet (CERS)

Remarks. First record in Saudi Arabia.

Chloropidae

Subfamily Chloropinae

Lasiambia sp. near albidipennis (Strobl 1893)

Specimens examined. 7q, Jazan, Abu Aresh, 4.x.2017; 15 ex. Alturatheya, mangrove, 4.x.2017; 7 O. Sabya, 16.x.2017, sweeping, U.M. Abu El-Ghiet (CERS).

Remarks. This is the first record from Saudi Arabia. Rhopalopterum sp.

Specimens examined. 1\%, Jazan, Sabya, 16.ix.2017, sweeping, U.M. Abu El-Ghiet (CERS).

Remarks. This is a new record species and at the genus from the Arabian Peninsula.

\section{DISCUSSION}

In this study, 39 species of Diptera belonging to 14 families were identified as the first time 20 species from southwest region in Saudi Arabia namely: Ophiomyia Arabica (Agromyzidae), Ommatius tenellus (Asilidae), Katacamilla cavernicola, Katacamilla ctenidia, Katacamilla procavia (Camillidae), Somatiosoma eremicolum (Chyromidae), Conops (Conops) tomentosus, Physocephala antiqua, Thecophora atra (Conopidae), Platypalpus albiseta, Platypalpus flavicornis, Platypalpus pachycera (Hybotidae), Leptometopa coquilletti (Milichidae), Efflatouniella vanharteni, Phycus rufofemoratus, Ruppellia semiflava (Therevidae). A further three taxa Phytoliriomyza sp. n. near hispanica Spencer, Lasiambia sp. near albidipennis (Strobl) and Rhopalopterum sp. could not be identified safely to species level because either there were no adequate identification keys, or a lack of males or possibly they belonged to a species group complex. These species were recorded as a new record because there is no species of the same genus recorded in this study (Table 2). Although it is very well known that Malaise traps are an excellent tool in collecting Diptera, in this study the number of specimens which were collected either by sweeping or Malaise trap was very low between 1-7 specimens taken into account the period of collection. It is the physical (temperature, rainfall) and biotic (human influence, predators, competitors and pathogens) factors which may limit the survival and reproduction of a species, and hence it's local density and geographical distribution (Hutchinson 1957). Out of 39 species in this study, we recorded 16 species from the Afrotropical Region, 13 species from the Palaearctic Region and two species from the Oriental Region. This result is consistent to some extent with studies that were carried out in these parts of Saudi Arabia, including Jazan and Farasan Island as having Afrotropical influences and should be included in the Afrotropical Region instead of Eremic zone or Palearctic Region (El-Hawagry et al. 2013, 2018; Dawah et al. 2020). The species recorded in this study belong to families the larvae of which live in terrestrial habitats apart from species of Ephydridae which were collected from mangrove in wet areas. Their larvae are known to feed in soil, deadwood, dung, nests, plants (leaf miners, gall makers), fungi and caves (Mathis \& Zatwarnicki, 1998) or as predators of frog eggs. The distinction between truly terrestrial and truly aquatic larvae is not always a clear one. These are not surprising results as most of the collection sites in this study are located in the arid area of southwest Saudi Arabia. This study added new records for Saudi Arabia which will provide the basis for future work on Diptera. Recently, 386 species of Diptera were the first time recorded in Saudi Arabia (H.A. Dawah, unpublished data). The number of Diptera species listed in Saudi Arabia so far would suggest that there remain more species to be discovered in the country if other provinces and localities are investigated with the use of mass trapping methods. Therefore, we expect that total number of Saudi Arabian Diptera species could be much higher.

\section{ACKNOWLEDGMENTS}

The authors are thankful to Jazan University for financial support under grant number $(r V / V / \cdots) \varepsilon)$. We introduce our appreciation to the Saudi Wildlife Authority in the Farasan Islands National Park for the provided facilities during the trails. We are also indebted to Dr. John Deeming from the National Museum Wales, Cardiff, Wales, UK, for identifying specimens. We would like to thank Dr J.C. Deeming and Mrs H.J. Dawah, Prof. Dr. Salah Ali Taleb and Dr. Maqbool Thaikkottathil, Dr. M. Ebejer, Dr D. Clements for their help and providing valuable information during investigation. 
Conflict of interest: The authors declare about this paper that they have no conflict of interest.

ORCID ID Usama M. Abu El-Ghiet https://orcid.org/0000-0003-0288-4199

\section{REFERENCE}

Abu-Zoherah R, Al-Taher K, Tilkian S (1993). List of Insects Recorded from Saudi Arabia, Ministry of Agriculture and Water, National Agriculture and Water Research Centre, Kingdom of Saudi Arabia, Riyadh. 394pp

Adler PH, Foottit RG (2009). Introduction. In: R.G. Fottit and Adler, P.H. (eds). Insect Biodiversity; Science and Society: 1-6. Blackwell Publishing Ltd. 632pp.

Ashburner M (1981). Entomophagous and other bizarre Drosophilidae. Chapter 10, pp. 395-429 in Ashburner, Carson and Thompson.Genetics and biology of Drosophila.

Askew RR (1971). Parasitic Insects. American Elsevier Publishing, Inc. New York. 316pp.

Badrawy HB and Mohammad SK (2011) Review of Ruppellia Wiedemann, 1830 (Diptera: Therevidae) in the Middle East. Zootaxa. 3097: 35-44

Barraclough DA (1998). Katacamilla Papp, 1978, a genus of Camillidae (Diptera: Schizophora) associated with the dung of bats and hyraxes in Africa and the Arabian Peninsula. African Entomology 6: 159-176

Barraclough DA (2004). First record of the Camillidae (Diptera: Schizophora) from Yemen. African Entomology 12 (2): 275-277

Beuk PL Th. (ed.) (2002). Checklist of the Diptera of the Netherlands. KNNV Uitgeverij, Utrecht. 448 pp

Bosák J, radský M (2011). Order Diptera, family Asilidae. In: A. van Harten (eds). Arthropod Fauna of the United Arab Emirates: 696-758. Dar Al-Ummah Printing, Publishing, Distribution \& Advertising, Abu Dhabi, UAE. 816pp

Cameron SA, Lozier JD, Strange JP, Koch JB, Cordes N, Solter LF, Griswold TL (2011). Patterns of widespread decline in North American bumble bees. Proceedings of the National Academy of Science of the United States of America. 108: 662-667

Canzoneri S, Meneghini D (1983). Ephydridae e Canaceidae. In: Fauna d'Italia. Vol. XX. Edizioni Calderini Bologna.xi $+337 \mathrm{pp}$

Chvála M (1983). The Empidoidea (Diptera) of Fennoscandia and Denmark. II. General Part. The families Hybotidae, Atelestidae and Microphoridae. Fauna Entomologica Scandinavica, Vol. 12. Scandinavian Science Press Ltd., Klampenborg. 279pp Chvála M, Kovalev VG (1989). Family Hybotidae. In: Á. Soós \& Papp, L. (eds). Catalogue of Palaearctic
Diptera.Vol. 6. Therevidae - Empididae: 174-228. Budapest, Hungary. 435pp

Chvala M, Smith KGV (1988). Family Conopidae. In: Á. Soós \& Papp, L. (eds). Catalogue of Palaearctic Diptera.Vol. 8. Syrphidae- Conopidae: 245-273. Budapest, Hungary. 363pp

Cogan BH (1980). Family Camillidae. In: R.W. Crosskey (eds). Catalogue of the Diptera of the Afrotropical region: 654. London. British Museum (Natural History). 1437pp

Cogan BH (1984). Family Ephydridae. In: Á. Soós \& Papp, L. (eds). Catalogue of Palaearctic Diptera.Vol. 10. Clusiidae - Chloropidae: 126-176. Elsevier Akadémiai Kiadó, Budapest and Elsevier, Amsterdam. 402pp

Collins KP, Wiegmann BM (2002). Phylogenetic relationships and placement of the Empidoidea (Diptera: Brachycera) based on 28S rDNA and EF-la sequences. Insect Systematic Evolution 33: 421-444

Courtney GW, Pape T, Skevington H, Sinclair BJ (2009). Biodiversity of Diptera. In: R.G. Fottit, \& Adler, P.H. (eds). Insect Biodiversity: Science and Society: 185-222. Blackwell Publishing Ltd. xxi 632pp.

Crosskey RW (1980). Catalogue of the Diptera of the Afrotropical Region. British Museum (Natural History), London. 1437pp

Dawah HA, bdullah MA (2006). The Ephydridae (Diptera: Brachycera: Muscomorpha) of south-western Saudi Arabia. Fauna of Arabia 21: 383-394

Dawah HA, bdullah MA (2006). New records of some Dptera: family Milichidae (cyclorrhapha) from Aseer, Southwest of Saudi Arabia, with some notes on their biology and distribution. Saudi Journal of Biological Sciences 14: 263-270

Dawah HA, Abdullah MA (2009). The Calliphoridae (Diptera: Cyclorrhapha) of south-western Saudi Arabia. Fauna of Arabia 24: 359-371

Dawah HA, Ahmad SK, Abdullah MA, Zatwarnicki T (2019). An overview of the Ephydridae of Saudi Arabia. Zootaxa. 4711 (3): 401445

Dawah HA, Abdullah MA, Deeming JC (2020). An overview of the Chloropidae of Saudi Arabia. Zootaxa. 4791 (1): 1-71

Deeming JC (1971). some species of Atherigona Rondani (Diptera: Muscidae) from Northern Nigeria, with special reference to those injurious to cereal crops. Bulletin of Entomological Research. 61: 133190

Deeming JC (1998). Milichiidae and Carnidae (Diptera: Cyclorrhapha) from the Arabian Penninsula. Fauna of Arabia 17: 147-157 
Deeming JC (2003). A contribution to the knowledge of African species of Oscinella Becker (Diptera: Chloropidae). Cimbebasia. 19: 81-94

Deeming JC (2006). Agromyzidae (Diptera: Cyclorrhapha) from the Arabian Peninsula. Fauna of Arabia 21: 395-423

Deeming JC (2008). Order Diptera, family Muscidae. In: A. van Harten (eds). Arthropod Fauna of the United Arab Emirates. Vol. 4: 714-723. Dar AlUmmah Printing, Publishing, Distribution \& Advertising, Abu Dhabi, UAE 754pp

Deeming JC (2011). Order Diptera, family Chloropidae. In: 784-806. In: A. van Harten (eds). Arthropod Fauna of the United Arab Emirates: 784806. Dar Al-Ummah Printing, Publishing, Distribution and Advertising, Abu Dhabi, UAE. 832 pp

Deeming JC (2017). Order Diptera, families Milichiidae and Carnidae. In: A. van Harten (eds). Arthropod Fauna of the United Arab Emirates Vol 6: 621-635. Printed by Department of the President's Affairs, Abu Dhabi, UAE. 775pp

Deeming JC, Al-Dhafer HM (2012). Chloropidae from the Arabian Peninsula (Diptera: Cyclorrhapha). Zoology in the Middle East 58: 1-88

Deeming JC, Baez M (1985). Some Milichiidae (Diptera, Cyclorrhapha) from the Canary Islands. Entomologist's Monthly Magazine 121: 63-69

Ebejer MJ (2007). Order Diptera, Family Chyromyidae. In: A. van Harten (eds). Arthropoda Fauna of the UAE. Vol. 1: 683-695. Abu Dhabi: Dar Al-Ummah Publishing. 754pp

El-Hawagry M, Khalil MW, Sharsf MR, Fadl HH, Aldawood AS (2013). A preliminary study on the insect fauna of Al-Baha Province, Saudi Arabia, with descriptions of two new species. Zookeys 274: 1-88 El-Hawagry MS, Abdel-Dayem MS, Elgharbawy AA, Al Dhafer HM (2016). A preliminary account of the fly fauna in Jabal Shada al-A'la Nature Reserve, Saudi Arabia, with new records and biogeographical remarks (Diptera, Insecta). Zookeys. 636: 107-139.

El-Hawagry MS, Abdel-Dayem MS, El-Sonbati SA, l-Dhafer HM (2017). A preliminary account of the fly fauna in Garf Raydah, Nature Reserve, Kingdom of Saudi Arabia, with new records and biogeographical remarks (Diptera: Insecta). Journal of Natural History 51 (25-26): 1499-1530

El-Hawagry MS, Abdel-Dayem MS, Al Dhafer HM (2018). A contribution to the knowledge of fly fauna in the Kingdom of Saudi Arabia: new country records and an account of flies identified from Rawdhats, Riyadh Region, with biogeographical remarks (Insecta: Diptera). Journal of Natural History 52 (21-22): 1377-1393

Evenhuis NL, Pape T, Pont AC, hompson FC (2007). Biosystematics Database of World Diptera, version 9.5. (Web page: http://www.diptera.org/biosys.htm) (Date accessed: June 2018).

Ferrar P (1987). A guide to the breeding habits and immature stages of Diptera Cyclorrhapha (Part I). Entomonograph, Vol. 8. E.J. Brill, Scandinavian Scinece Press, Leiden and Copenhegan. 478pp

Freeman BA (1966). Notes on conopid flies, including insect host, plant and phoretic relationships (Diptera: Conopidae). Journal of Kansas Entomological Societies 39: 123-131

Freidberg A, kugler J (1989). Fauna Palaestine Insect IV Diptera: Tephritidae. 212pp

Friedberg A (1974). Descriptions of new Tephritidae (Diptera) from Israel. Journal of the Entomological Society of Southern Africa 37(1): 49-62

Gibson JF, Skevington JH (2013). Phylogeny and taxonomic revision of all genera of Conopidae (Diptera) based on morphological data. Zoological Journal of the Linnaean Society 167: 43-81

Hauser M (2017). Order Diptera, family Therevidae. In: A. van Harten (eds). Arthropod fauna of the UAE. Vol. 6: 538-564. Department of the President's Affairs, Abu Dhabi, UAE. 775pp

Hutchinson GE (1957). Concluding remarks.Cold Spring Harbor Symposium. Quantitative Biology 22: 415-427

Irwin ME, Lyneborg L (1981a). The genera of Nearctic Therevidae. Bulletin of the Illinois Natural History Survey 32: 193-277

Irwin ME, Lyneborg L (1981b). Therevidae. In: J.F. Mc Alpine, B.V. Peterston, G.E. Shewell, H.J. Teskey, J.R. Vockeroth and D.M. Wood (eds). Manual of Nearctic Diptera, Vol.1: 513-523. Monograph, No. 27. Research Branch, Agriculture Canada 674pp

Kahanpaa J (2014). Checklist of the Empidoidea of the Finland (Insecta, Diptera). ZooKeys 441: 183-207 Khaghaninia S, Kazerani F (2014). Contribution to the knowledge of thick-headed flies (Diptera: Conopidae) of Iran II; Myopinea, Sicinae and Zodioninae. Biharean Biologist 8(2): 75-82

Kirk-Spriggs AH, Sinclair BJ (2017a). Manual of Afrotropic al Diptera. Vol. 1. Introductory chapters and keys to Diptera families.Suricata 4. Pretoria: SANBI Graphics and Editing. Xiii 425 pp

Kirk-Spriggs AH, Sinclair BJ (2017b). Manual of Afrotropical Diptera. Vol. 2.Nematocerous Diptera and lower Brachycera.Suricata 5. Pretoria: SANBI Graphics and Editing. 1361 pp 
Kirk-Spriggs AH, Barraclough DA, Meier R (2002). The immature stages of Katacamilla cavernicola Papp, the first described for the Camillidae (Diptera: Schizophora) with the comparison to other known Ephydroidea larvae and notes on biology. Journal of Natural History 36: 11051128

Lehr PA (1988). Family Asilidae. In: Á. Soós and L. Papp, L. (eds). Catalogue of Palaearctic Diptera. Vol. 5. Athericidae-Asilidae: 197-326. Akadémiai Kiadó, Budapest and Elsevier, Amsterdam 446pp

Lyneborg L (1980). 24. Family Therevidae. In: R.W. Crosskey (eds). Catalogue of the Afrotropical Region: 314-320. British Museum (Natural History), London. $1437 \mathrm{pp}$

Lyneborg L (1989). Family Therevidae. In: Á. Soós and L. Papp, L. (eds).Catalogue of Palaearctic Diptera, Therevidae-Empididae. Vol. 6: 11-35. Budapest, Hungary. 435pp

Majer JM (1997). Family Therevidae. In: L. Papp and B. Darvas, B. (eds). Contributions to a Manual of Palaearctic Diptera, Nematocera and Lower Brachycera, Vol. 2: 519-529. Science Herald, Budapest 592pp

Marshall SA (2012). Flies the Natural History \& Diversity of Diptera. Firefly Books Ltd, Ontario, Canada 616pp

Martin OY, Puniamoorthy N, Gubler A, Wimmer C, Germann C, Bernasconi MV (2013). Infections with the microbe Cardinium in the Dolichopodidae and other Empidoidea. Journal of Insect Science 13(47): 1-13

Mathis WN, Zatwarnicki T (1995). A world catalog of the shore flies (Diptera: Ephydridae). Memoirs on Entomology, International, Associated Publishers, Grainesville, FL 4: 1- 423

Mathis WN, Zatwarnicki T (1998). Family Ephydridae 3.49. In: L. Papp \& Darvas, B. (eds). Contributions to a Manual of Palearctic Diptera (with special reference to flies of economic importance). Vol. 3 Higher Brachycera: 537-570, Science Herald, Budapest, 880pp

Merritt RW, Courtney GW, Keiper JB (2003). Diptera (flies, mosquitoes, midges, gnats). In: V.H. Resh and R.T. Cardé (eds). Encyclopedia of Insects: 324-340. Academic Press, London. 1266pp

Mukhopadhyay E, Naskar A, Hazra S, Maity A, Sengupta J, Parui P, Banerjee D (2015). A checklist of Indian Thick headed flies (Insecta: Diptera: Conopidae). Zoological survey of India, M Block, New Alipore, Kolkata-700053.7pp
Norrbom AL,Condon M (2010). Revision of the femoralis group of BlepharoneuraLoew (Diptera: Tephritidae). Zootaxa 2374: 1-139

Oldroyd H (1980). 28.Family Asilidae. In: R. W. Crosskey (eds). Catalogue of the Diptera of the Afrotropical Region: 334-373. British Museum (Natural History), London, U.K. 1437pp

Okaeme AN (1983). Notes on Acalypterates (Diptera) as pest of cattle. Bulletin of Animal Health Production of Africa 31: 255-256

Pape T, Thompson FC (eds.)(2013). Systema Dipterorum.Version 1.5. Available from: http://www.dintera.org

Papp L, Darvas B (1998). Contributions to a Manual of Palearctic Diptera.Vol. 3. Higher Brachycera, Science Herald, Budapest, 880pp

Papp L (1978). Some cavernicolous Diptera of Geneva museum. Revue Suisse de Zoologie 85: 99106

Papp L (1984). Family Milichiidae. In: L. Papp \& Soós, Á. (eds). Catalogue of Palaearctic Diptera: 110118. Akadémiai Kiadó, Budapest and Elsevier, Amsterdam. 402pp

Pont AC (1973). A review of the Oriental species of Atherigona Rondani (Diptera: Muscidae) of economic importance. In: M.G. Jotw ani and W.R. Young, W.R. (eds). Control of Sorghum Shoot Fly: 27-102. New Delhi, Oxford \& IBH Publication, Co 324pp

Pont AC (1980). 85 Family Muscidae. In: R. W. Crosskey (eds). Catalogue of the Diptera of the Afrotropical Region: 721-761. British Museum (Natural History), London 1437pp

Pont AC (1986). Families Fannidae, Muscidae. In: Á. Sóos \& Papp, L. (eds). Catalogue of Palearctic Diptera, Scathophagidae-Hypodermatidae: 57-215. Budapest. 346pp

Pont AC (1991). A review of the Fanniidae and Muscidae (Diptera) of the Arabian Peninsula. Fauna of Saudi Arabia 12: 312-265

Sabrosky CW (1980). 80. Family Chloropidae. In: R. W. Crosskey (eds). Catalogue of the Afrotropical Region: 695-712. British Museum (Natural History), London 1437pp

Sabrosky CW (1983). A synopsis of the world species of Desmometopa Loew (Diptera: Milichiidae). Contributions of the Americ an Entomological Institute 19 (8): 1-69

Schmid-Hempel P, Müller CB (1991). Do parasitized bumblebees forage for their colony. Animal Behaviour 41: 910-912

Skevington JH, Thompson FC, Camras S (2010). Conopidae (Thick-Headed Flies). In: B.V. Brown, A. Borkent, J.M. Cumming, D.M. Wood, N.E., Woodley 
and M.A. Zumbado (eds). Vol. 2: 847-855. NRC Research Press, Ottawa, Canada1442pp

Skidmore P (1985). The Biology of the Muscidae of the World. Series Entomologica, 29, XIV, $550 \mathrm{pp}$

Skuhravá M, Martinez M, Roques A (2010). Diptera. In: A. Roques, Kenis, M., Lees, D., LopezVaamonde, C., Rabitsch, W., Rasplus, J-Y \& Roy, D.B. (eds). Alien terrestrial arthropods of Europe: BioRisk 4 (1) (special issue): 553-602

Smit JT, van Harten A, Ketelaar R (2017). Order Diptera, family Syrphidae the hoverflies of the Arabian Peninsula. In: A. van Harten (eds). Arthropod fauna of the UAE Vol. 6: 572-612. Department of the President's Affairs, Abu Dhabi, UAE. $775 \mathrm{pp}$

Smith KGV (1980). Family Conopidae. In: R.W. Crosskey(eds). Catalogue of the Afrotropical Region: 511-517. BritishMuseum (Natural History), London. $1437 \mathrm{pp}$

Smith KGV, Peterson BV (1987). Conopidae. In: J.F. Mc Alpine, B.V. Peterston, G.E. Shewell, H.J. Teskey, J.R. Vockeroth and D.M. Wood(eds). Manual of Nearctic Diptera. Vol. 2: 909-912. Monograph 28. Research Branch, Agriculture Canada 575-1332pp
Soós Á, Hůrka K (1986). Family Hippoboscidae.In: Á. Soós\& PappL. (eds.), Catalogue of Palaearctic Diptera, Vol. 11: 215-226. Akademiai Kaido, Budapest Hungary.

Stuke J, Hayat R, Özbek H (2008). Records of notable Conopidae (Diptera) from Turkey. Faunistische Abhandlungen (Dresden). 26: 109-117

Stuke JH (2017). World Catalogue of Insects; Conopidae (Diptera). Volume 15. Brill Academic Publishing. pp 225

Tsacas L (1980). 74. Family Drosophilidae, 673-685. In: R. W. Crosskey, W.R. (eds). Catalogue of the Diptera of the Afrotropical Region: 673-685. British Museum (Natural History), London. 1437pp.

Walker DH, Pittaway AR (1987). Insects of Eastern Arabia. Patron: H.E. Sheikh Nahayan bin Mubarak AlNahayan, Emirates Natural History Group 175pp Winterton SL, Hardy NB, Gaimari SD, Hauser M, Hill HN, Holston KC, Irwin ME, Lambkin CL, Metz MA, Turco F, Webb D, Yang L, Yeates DK, Wiegmann BM (2015). The phylogeny of stiletto flies (Diptera: Therevidae). Systematic Entomology 41(1): 144-161

Yang D, Zhang KY, Yao G, Zhang JH (2007). World catalogue of Empididae (Insecta: Diptera). China Agricultural University Press, Beijing. 599pp 
Scientific Journal of Agricultural Sciences 3 (2): 204-218, 2021

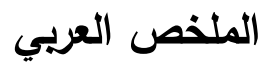

\title{
مساهمة في فونا ثنائية الأجنحة مع بعض التسجيلات الجديدة المميزة للأنواع.
}

\author{
أسامة محمد أبو الغيط'، ، طارق محمد الشيخ'، ، زرلق عيسي الفيفي'، حسن علي دواح؛ \\ 'قسم الأحباء. كلية العلوم ، جامعة جازان ، المملكة العربية السعودية.

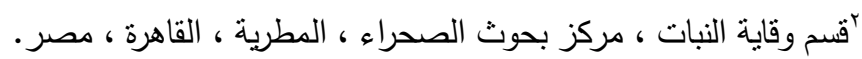

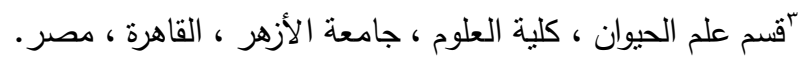 \\ كركز البحوث والدراسات البيئية . جامعة جازان ـ المملكة العربية السعودية.
}

على الرغم من ثراء نباب ثثائيات الاجنحة (النباب الحقيقي) وأهميتها الييئية والطبية والزراعية ، إلا أنها لم تدرس بشكل جيد في المملكة العربية

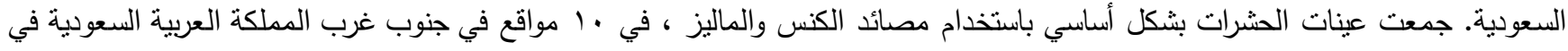

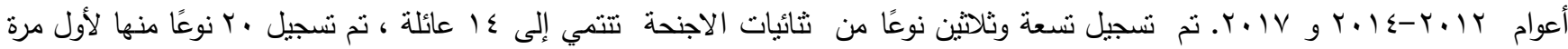
في جنوب غرب المملكة العربية السعودية وهي :

Ophiomyia arabica Deeming, Phytoliriomyza sp. n. near hispanica Spencer (Agromyzidae), Ommatius tenellus Van der Wulp (Asilidae), Katacamilla cavernicola Papp, Katacamilla ctenidia Barraclough, Katacamilla procavia Barraclough (Camillidae), Lasiambia sp. near albidipennis (Strobl), Rhopalopterum sp. (Chloropidae), Somatiosoma eremicolum Ebejer (Chyromidae), Conops (Conops) tomentosus Kröber, Physocephala antiqua (Wiedemann), Thecophora atra (Fabricius) (Conopidae), Platypalpus albiseta (Panze), Platypalpus flavicornis (Meigen), Platypalpus pachycera (Collin) (Hybotidae), Leptometopa coquillettiHendel (Milichidae), Efflatouniella vanharteni Hauser, Phycus rufofemoratus Kröeber, Ruppellia semiflava Wiedemann (Therevidae).

أضافت هذه الدراسة تسجيلات جليدة من نثائيات الاجنحة وستوفر الأساس للأعمال المستقبلية على النباب. نقترح أنه سيتم الكثف

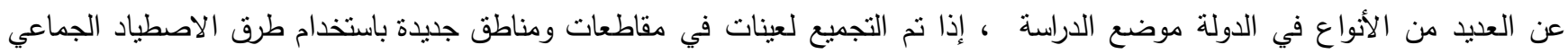
المنتوعة.

الكلمات المفتاحية : Diptera. فرسان. جازان ، أبها ؛ سجلات جليدة المملكة العربية السعودية. 